\title{
7 \\ To the Bottom of the World
}

I was just over six years old and my brother three when World War II caught up with us in Iran. We were living in the north-west of the country quite close to its border with Iraq. My father was building a railway and upgrading the road through a mountain pass. We were based in a company-owned house at the edge of the Kurdish village of Karind.

I remember it very well: the mud-baked houses with their flat roofs, clinging to the slopes of the valley; the nearby cemetery with its tombstones engraved with the goats owned and cherished for a life-time; the fastflowing stream moving through a dense thicket beyond the village. Above it, black-and-white butterflies as large as your hand floated in filtered light.

I remember also the wind-up gramophone which mother used to place on the table on the back verandah. Perhaps it would be a movement from Mendelssohn's first piano trio floating towards the mountains and mingling with mother's feelings of melancholy. I still have the record.

Elfriede had followed Rudolf to this remote region with two young children and a large dog. When she arrived she was nursing a wound from dental surgery in Tehran. One of her cheeks was bloated, and she disguised it under a scarf.

Her toothache added to her feelings of unease. How safe was the family in this Kurdish settlement? The European War had already moved beyond Europe's boundaries. I, of course, was oblivious to all this. In later life my mother occasionally berated Rudolf with her tongue for his impulsive, impractical ways. Although I always knew him as a responsible 
breadwinner, considerations of practicality and indeed of family safety sometimes ended up well behind his passion for his profession. The more remote the location and the more challenging the work, the better he liked it.

Mother had lived with this since her marriage. It gave us our adventurous life. His exploits, such as the car and driver being swept away, or the road through the mountains at night ending in a ravine without a bridge, became grounds for recrimination. They grew into dragons' teeth.

The War appeared as a single aeroplane with circles on its wings. On that fateful day, my mother had scrubbed my head and was brushing out my tangled hair. We were in the lane outside our front door, and I was protesting angrily.

My mother was an intelligent parent who paid attention to new scientific ideas about vitamins, including the healing powers of sunshine. She had taken me outside to catch some morning sun. I spotted the pale aeroplane rumbling towards us over the mountains. It began to descend and fly low over the village.

Mother dropped the brush and rushed out of the lane to see better. When she saw that the plane was British, she burst into tears. 'That's the end of us,' she cried. She came and held me close.

The plane circled a couple of times, then disappeared. It was obviously on a reconnaissance mission. An invasion was clearly imminent, even though Karind lay in difficult terrain.

Before this day, my parents had been wondering what to do with me. Within the year I was to turn seven, the age at which children were sent to school in Germany. Although I had not been told, my parents had arranged that I should lodge in Tehran with an Iranian doctor and his German wife. The doctor had studied in Germany. I was to attend the International School while living in their house.

Had the War not intervened, our family may well have remained in Iran. I might even have married there and now be living surrounded by modern Iran's religious communities. But the hand of fate moved us in another direction on life's chessboard.

If I had been sent to school, of course, I would have been separated for years from my parents. I was to be saved this trauma. 
Next day, as I was playing with the local Kurdish children in the lane outside our house, I heard a loud rattle and saw a green metal vehicle with a long gun in front rolling towards us. Its bulk took up most of the space between the houses. I pressed myself against the wall and watched with trembling fascination. This engine of war did not stop at our house, but moved beyond the settlement. Village children swarmed behind it. I stayed close to home.

Later, as my family was lunching on the verandah at the back of the house, facing a derelict garden and a sluggish creek, soldiers in khaki climbed through an opening in the baked mud wall. They kept on coming until there seemed to be about a dozen. They immediately surrounded us, standing in a wide circle, each aggressively pointing at us the bayonet tied to his rifle.

'Don't move. Stay where you are,' an English officer commanded, in most peculiar German. We immediately put our cutlery down on the table. Turning to my father, he shouted: 'Hands up above your head!', then led him away like a thief. We did not see our father again for two days.

I was told in later years that the person in charge of the soldiers' camp was Sir William Slim and that the day of this momentous happening was 30 August 1941.

In May, British troops had entered Iraq to protect their oil interests. When Hitler's forces attacked the Soviet Union in June, it joined Britain in an invasion of neutral Iran, to protect landlines for their war supplies. Reza Shah abdicated, and his son ascended the Peacock Throne as Mohammad Reza Shah Pahlavi.

The villagers had been asked by the soldiers who found us if any foreigners lived nearby. It was many years before I learned anything about my father's interrogation, about how he was offered no food for those two days, but was obliged to come home for his meals under military surveillance. Over those days, he tried in vain to convince the soldiers that he was not in the pay of the German government. No, he told them, he was not a German spy.

The British papers of the time told stories of several thousand agents of the Third Reich in Iran, thinly disguised as German professionals. A list of the names of seventy allegedly active agents was leaked. Rudolf's name was not among them. 
My father's captors offered him a car and protection for his family if he was willing to become a secret agent for the British government. He was one of twenty civilian internees deemed to have considerable knowledge of Iran and Iranian grassroots politics. 'No,' he was supposed to have said, 'I am not prepared to spy for any government.'

This was the wrong response. On 1 September, my mother was told to pack everything up, at once. Each family member was to be assigned no more than a certain weight-I think thirty kilos. We were to leave in a few days.

A group of soldiers guarded our house around the clock. In the tent where he was a prisoner, my father became more and more anxious about what was happening to his family. What was going on: rape, plunder, bribery, blackmail, theft? He also brooded on the insensitivity of his removal. Dragged away from his loved ones, he had been treated like a criminal. According to my mother, who only read it fifty years later, after he died, he recorded in his diary that on a visit home for food two days after his imprisonment, he had glimpsed through a window his wife in a compromising position with a British officer.

Why did he write this? A projection of his fear? A fantasy of his captivity? Anger with his wife over a marriage that was under threat? Perhaps my mother had later accused him of landing us in this mess. And she always admired the English.

I doubt that there was any truth to this story. Indeed, Elfriede would not have told me such an incriminating tale against herself had it been true. She never confided intimate details of her life to me. She was a stickler for a repressive form of sexual morality in conversation with the children. It was also unlikely that Rudolf, under military guard, had the opportunity to spy on his own house.

My mother told me she had destroyed the offending page. She probably destroyed the diary itself, since I have never seen it. For me, this distasteful incident illustrates how confusing and alarming were the circumstances of our abrupt capture.

Elfriede was then forced to make nervous decisions about what to pack, without Rudolf's advice. A military doctor came to check our health. He reproached my mother rudely for 'burning' my scalp with kerosene 
in her attempt to rid me of the lice I had acquired from associating with the village children. He advised her to apply soothing black tea to the wounded skin.

I was annoyed with him for the belittling tone with which he addressed my mother. But I could not grasp his position as an 'enemy'.

The larger body of William Slim's group then moved on, leaving us in the charge of a few armed Gurkhas. The doors and windows of our house were boarded with wood, and many of our possessions were left inside.

Our dog was given to the Iranian police. I saw him leave in chains in the back of a van. He howled and I fretted. At times I had felt I loved him more than my family. He had always fussily protected Peter and me and risked his own safety for us, walking on the side where danger might lurk. My father was informed years later by a Danish neighbour that Fram had kept escaping from police custody and returning to the house after we had gone, looking for us and kicking up a terrible racket.

According to family memory, we left Karind on 16 September. We and the possessions we were permitted to take with us, in a few suitcases and crates, were loaded on to military lorries. My mother and I sat in front beside the driver, with my father and brother behind in the back, under olive green canvas.

Several military jeeps drove in convoy to Basrah in the south. What possessions had my mother packed? Much later I discovered that they were more than such a hurried departure warranted. They included valuables like carpets and silver, possibly to sell in an emergency; practical things like clothes and her Singer sewing machine; items of great sentimental value, like photograph albums and the HMV gramophone; and exotica from Iran such as a samovar.

The military convoy made several stops, the first at the town of Kermanshah, where my father was separated from us. We did not see him again for several weeks. The British did not want to take wives and children into custody, and encouraged internees from Iran to send their families 'home'. I do not know who insisted that our family not be divided. In an emergency my wiser, practical mother usually took the lead. She could be a tigress in our defence. 
At the Basrah detention camp in which we were placed until our departure by ship could be arranged, our parents were interrogated separately and continuously, as if they were harbouring deep secrets which they were unwilling to divulge. My father was forced to live away from us the whole time.

My mother told me much later, dramatising her forcefulness and character, how British intelligence officers had asked her, in German, about her political affiliations. 'Rudolf and I have never been members of any political party,' she told them. 'We don't know in any detail what's going on in Germany. But if you put us into a prison camp with a bunch of Nazis we may not have much choice but to join them. They seem to put huge pressure on other people. That's what they may do to us, and that's the risk you take,' she threatened, hoping to reverse the decision to remove us from Iran.

But it was all in vain. Rudolf was unable to convince his interrogators that he was simply an engineer doing his job, not an agent of the Third Reich.

I was to read as an adult in William Slim's Unofficial History that he was convinced that the 3,000 or so citizens of Germany working in Iran were in the service of the Nazi government. According to Iranian sources, there were only a few hundred Germans in the country with their families. I was also to discover that when Britain entered the War, Winston Churchill gave the order that all German and Italian citizens in countries with a British sphere of influence were to be interned: 'Collar the lot' was the order given. Although Iran was not a British possession, the country had a share in its oilfields. Citizens from nations of the Axis alliance were seen as a danger to its interests.

In our compound at the Basrah camp, Peter and I played carefree games. From the shell-grit paths we took the larger bi-valve and smaller spiral shells and made tea sets for imaginary little companions. Peter turned shells into cars, aeroplanes and trains. Our concentrated attention on our games distracted us from our mother's hours of absence as she was questioned.

The Gurkha guards in their camouflage uniforms indulged our games good-humouredly. After a day's intense heat, with other women, they took my mother and us - but not the men-for walks along the banks of the wide Shatt-al-Arab. Or was it one of its canals? Tall palms grew at 
intervals. The water shimmered a lustrous black. Shafts of light crossed it from bank to bank. A hint of swamps and of sea salt hung in the air. The river suggested voyages, trade, leisure for the local inhabitants.

When the Gurkha garrison left us, formidable, grim Sikh guards in white turbans replaced them. Generally taller than our friendly Gurkhas, they stared down on us severely. They commanded us with brisk words. They stopped Peter and me from plucking shells from the paths. They stopped our walks. They were uncompromising. They made us uncomfortable.

One day we were put on a British ship called the Rona. The men were separated from their families. This was the first time we saw our father again after his long absence. He stood in the open part of the hull, waving to us from the huge group of dispirited men.

The ship was not comfortable. Conditions for the men were terrible. Bitter complaints arose about their crowded sleeping quarters and the few toilets that were meant to serve everyone. To shouted questions, women's voices replied reassuringly from the deck overlooking the men's quarters.

The ship made a slow passage along the swampy, meandering river cluttered with small obstacles. Years on, once in a while, that river appears again in dreams. In one such dream, I stretch my hands over the railing to pull at a branch, so close seems the land. In another I call in vain to people on the shore to help us get off that ship.

On that real day in October 1941, however, we children felt no real dread. It was exciting for us to move along to who knows where.

Then suddenly our vessel reached the river's mouth and the Persian Gulf. There was no stopping us now. The wind was blowing strongly, and waves heaved the ship forward into the ocean. She gathered speed. A frothy trail behind the Rona showed we were moving ever further from the groves of palm. Impulsively we waved goodbye to no one but the land which had nourished us. We watched the shore as it grew ever fainter, until it disappeared altogether.

We travelled to our destination, Bombay, with father mostly hidden below and mother with us in our cabin above. We were to be interned in India. At Bombay Harbour, with the hand luggage and cases that our mother had packed, we waited for the signal to disembark. We also waited to meet up with Rudolf. 
Instead, without warning, everybody was ordered to board the Rangitiki, a large New Zealand ship which had appeared beside the Rona. A gangplank was placed between the two vessels. As Bombay vendors jostled with each other for trade in a congestion of small boats, we walked the plank from ship to ship, above thick rope netting. It was a terrifying moment.

When we found the cabins that had been assigned to us, we were delighted to be reunited with our father. The few families now had the first-class cabins, while nearly 500 men on their own remained crowded together. Perhaps the Rangitiki was a larger ship, perhaps the fathers had been wellbehaved and could now be trusted to join their families. The adults were told that a famine in India had caused the change of plans.

Arrangements had been made to send us to Australia. 'Australia?' my parents exclaimed, never having contemplated such a move. They knew little about the country except from coloured calendars that presented rolling plains and Aborigines with spears hunting kangaroos. Our parents were not pleased to be on the way to 'the bottom of the world', to a land without big cities and, as they saw it, without history or civilisation.

At the time no one mentioned the change of plan as perhaps determined by anti-colonial sentiments in India. It would not have been wise to have enemy aliens among people agitating to throw out their British masters.

Many years after these events I was to learn how our British captors, in an arrangement with the Australian authorities, were able to send us there. Officially we were prisoners of the British government, but Britain was prepared to repay Australia for the cost of our internment to get us out of the Middle East, where we were simply in the way. A military garrison would receive us in Australia.

As we awaited departure, some trading took place. Father had been allowed to keep a small amount of money from a larger sum that had been taken from him in Kermanshah, with a promise (not fulfilled) of its return. He bartered for a hand of bananas and some coconuts. Peter and I watched as a delightful family of three ebony elephants rose up to us in a basket. They were ceremonially received, one by one. Then our indulgent parent sent the money down to an eager face in a canoe below. 
We made the crossing from India via Colombo to Singapore, and from there down to Australia, with a Scottish military garrison. An armed warship steamed in front, others followed behind. We children took daily interest in the grey convoy of military ships as we moved through the Indian Ocean.

Every afternoon before sunset, soldiers in kilts marched up and down the deck playing Scottish tunes on their Dudelsäcke (bagpipes). At sunset a bugler performed the Last Post. On one such occasion the Cocos Islands lay in the distance to the south of the ship as Scottish warriors strode up and down with their pipes. I was to recognise some of the tunes and words years later in my Australian school, especially the refrain Will ye no' come back again? and Speed bonnie boat like a bird on the wing.

Fond relationships have been known to grow between captors and captives. During the journey we attached ourselves to some members of this Scottish garrison. They were men with families at home and our presence was a reminder of what they were missing. I recall especially a Captain John, who treated the women with attentive civility, who joked with us children and gave us a number of privileges.

One evening, somewhere in the Indian Ocean, a loudspeaker sounded the alarm and declared a submarine alert. I heard the word 'Japanese'. The whole ship was suddenly blacked out for about two hours. But what if it was a German submarine come to destroy the British ships, not knowing we were on board? Although we had been reassured that we were probably safe, the strictest precautions were imposed. An explosion, fire, or a sinking ship hovered uneasily in the realm of possibility.

The ship remained in darkness for some time after the emergency had passed. We were then permitted to walk on deck, still in the dark. Between curtains of mist, stars had gathered in great shoals. Below us, against the iron sides of the ship, waves broke. Marine 'glow-worms' flashed in the foam, like tiny torches chasing one another.

When the ship's lights came on again, I was ordered into bed. Even a War on the horizon made no difference to the domestic rules that governed our lives. When there was no emergency, bedtime was always seven o'clock.

We had been prepared for the possibility of an attack at sea. Periodically, we were ordered to carry our life jackets up the steep iron steps. Children staggered under these awkward bundles. Younger children were 
carried by their parents. Everyone was ordered to go through the drill, gathering by the lifeboat assigned to them. One day we might really have to jump into the sea. This was too terrible to contemplate. The ship was so tall and the sea so far below! I had never liked heights. They made me dizzy. 'What if we really had to jump?' I thought. 'I'd rather turn into a stone or die on the spot.'

Every day there was also an ordinary routine, as our time was measured out by the bells that summoned us to meals. Then there were other routines imposed by our parents, like the time to get out of bed or to put out the lights over our bunks in the evening.

These routines were enlivened by getting to know others on the ship. I remember a Jewish doctor, Dr Fuchs, telling me a sequence of gripping fables he had improvised. My brother and I were cast as the white good sheep (myself) and the black naughty sheep (Peter). Then there was the wily, wicked wolf playing his clever games. I well remember my growing sense of disquiet that I should be favoured over Peter. 'Surely we should change parts occasionally?' I demanded, confronting Dr Fuchs with my mother's sense of justice. But my protest displeased him and he stopped the game.

He did, however, know others. He gave me a pair of his blackened surgical scissors, which I used to make paper cut-outs. I used the scissors so much that he eventually gave them to me as a souvenir of our voyage.

The few privileged adults assigned the cabins on the ship interacted with mutual gracious concern. My parents spoke of them with respect. There was Franz Zubeck, who told us he was the Professor of Music at the Tehran Conservatorium. Then it was noticed that he was mentally disturbed. Nevertheless, I was fascinated by his virtuoso performances of Tartini's The Devil's Trill, since my father had plans that I should learn the violin myself one day. I secretly came up with the view that a man who plays for the Devil is a shady character.

Zubeck's wife, his sixth, was quite different. A fashion designer, she made me a cut-out paper doll to clothe. She added, piece by piece, a wardrobe of paper clothes for different occasions: tennis, skating and hunting outfits, party dresses, a night-gown, a bridal gown, a riding jacket. These paper ensembles were cunningly made, decorated in pencil with fabric patterns, trimmings of fur, bows and laces. Madame Zubeck painted the doll's lips with real lipstick. 
I noticed that my mother, who had been stylish in urban Iran, gave up wearing cosmetics from the day that she was imprisoned. Madame Zubeck, however, still painted her face. Mother's appearance was to continue to change over the next five years, turning a once-elegant woman into a dowdy Hausfrau. She acquired the look of deprivation seen in many prisoners. She suffered her fate with apparent resignation, but I could sense how disturbed she was in spirit.

The Zubecks and Dr Fuchs, because they befriended me so graciously, impressed me most. I have no recollection of the other families who travelled with us, not even the other two children.

Peter and I shared cabin space and a double bunk, his underneath mine. One day, although I was six years old and ought to have been better informed, I tested whether humans could really fly. I took the risk of leaping offthe top bunk with outstretched arms. I crashed on my head. Although I was not injured, I never doubted my frail mortality again.

My moments of arrogance never got me far. The lesson of my tiny presence in the vast universe was reinforced as I watched the sea washing past our port-hole, sometimes covering it altogether. What wild beasts, what monsters of the deep, lurked in these depths, I wondered?

Before Singapore we entered a thick fog. We stayed blindly in it for a long time. To a young child it seemed like two or three days. Then one morning we woke up to a harbour full of trading boats, just as we had seen in Bombay.

No one then knew that Singapore would soon be captured by Japanese soldiers. Father again bought a hand of bananas and some coconuts. By the time our convoy sailed on, the mists and fogs had dispersed. We sailed past islands where groups of figures, dressed in long white robes, waved to us. They could not have known that we had become undesirables. We returned the greeting. I was sad when we left the friendly world of islands and entered the open sea once more. In later years I imagined that Shakespeare's Tempest had taken place in such a world.

Most days the horizon moved up as the ship tilted on one side, and down as she rose again on the other. Motion was constant, water squelching below, streaming past, frothing. On calmer days, the ship's wake amused me and my brother. We watched fish flying in arcs of silver. Several times a group of dolphins adopted the Rangitiki and swam alongside with 
playful purpose. We acquired sea legs which scampered up and down the steep iron stairs. These were bonded, bolted, riveted, a reminder of tough work and tough times. Then there were the more domesticated wooden kind, for tamed travellers. We children became knowledgeable about our floating carrier. But we knew some areas were out of bounds.

At the end of our journey, we berthed in Adelaide harbour. I do not remember leaving the ship, although the pain of being parted from Captain John had us children, and some of the women, in tears. He cried as well.

I do not recall angry shouts of 'Nazis!' at the wharf from the crowd of Australians who had gathered there. That incident I heard of later, from someone else, not my family. My brother Peter stresses the civility with which my mother was helped to disembark by an Australian soldier. He carried her case to the wharf and welcomed her to Australia. This makes me wonder whether there was an angry crowd at all.

Electric light poles were silhouetted against a dark red November sunset as we boarded the train that took us to the railway station in central Adelaide. Children do not take in much information when adults are looking after the packing, unloading and re-stacking of luggage. Nor do they understand much of those formalities that are adult concerns during such a heavily guarded journey. So the sunset remains in my mind at the end of the long journey, not the inflexible rules that were propelling us into a prison camp.

We boarded the steam train that ran between Adelaide and Melbourne. Sitting up all night, we stared out and wondered what this Australia was like outside. But we saw only our own reflections in the windows.

Later someone told me that the windows of the train had in fact been covered with newspaper. Could that have been true?

From Melbourne we were taken by bus on a very long ride to the rural district of Tatura, in northern Victoria. We arrived in daylight. In late November 1941, with the onset of the early summer heat, it seemed a desolate place. A few dull trees stood in dry, cleared land. We saw before us the corrugated iron huts and the barbed wire of Prison Camp No. 3, the civilian family camp. Much later in life I learned that the land belonged to the pastoralist-politician, 'Black Jack' McEwan. The Army had requisitioned it from him, supposedly for a substantial sum. 
This text is taken from At Home in Exile: A Memoir, by Helga M. Griffin, published 2021 by ANU Press, The Australian National University,

Canberra, Australia.

doi.org/10.22459/AHE.2021.07 